\title{
Estimation of Variability in Red Rot Inoculated and Un- Inoculated Early Maturing Sugarcane Clones for Cane Yield and Juice Quality Traits
}

\author{
Sara Neelofer* and Balwant Kumar
}

\author{
Plant Breeding and Genetics, S.R.I., Dr. R.P.C.A.U., Pusa, Samastipur-848 125, Bihar, India \\ *Corresponding author
}

\begin{tabular}{|l|}
\hline Ke $\mathbf{y}$ w o r d s \\
Variability, PCV, \\
GCV, Heritability, \\
GA as percentage of \\
mean, Red rot \\
(Colletotrichum \\
falcatum) disease \\
score.
\end{tabular}

\section{Introduction}

Sugarcane occupies a position of pride as an agro-industrial crop of the country. Sugar industry is the only agro - based industry in Bihar and second largest after textile in India. The industry generates sizeable employment in the rural sector directly and through ancillary industries. The farmers and their dependents get engagement through the cultivation of sugarcane and hundreds of skilled and unskilled workers including highly qualified and trained technologists are engaged in the manufacture of Sugar in every sugar mill. The sugar industry in Bihar will have to produce 1.5 million tonnes of sugar from 15.0 million tonnes of sugarcane with sugar recovery of 10 per cent in order to make the state self-sufficient, the annual per capita consumption being $15 \mathrm{~kg}$. This will 
only be possible by production of sugarcane to the tune of 30.0 million tones considering the fact that 60 per cent of the total produce would be made available at the factory gate, the rest of raw material used for seed, chewing and production of non-centrifugal sweeteners (Gur). During 2016, about 0.50 million tonnes of centrifugal sweeteners (white sugar) was produced in Bihar from total production of 13.90 million tonnes of raw material in an area of 0.28 million ha, the sugar recovery being 9.77 per cent (Indian Sugar, June, 2017). In order to bridge the wide gap the sugar and sugarcane production would have to be more than tripled with 0.5 per cent enhancement in sugar recovery by growing high yielding varieties of sugarcane having better juice quality, resistance to major disease and pests with wider adaptability. The area under the crop cannot be increased by more than 5 million ha due to pressure for growing food grains, oilseeds, pulses and coarse grain to feed the ever growing population. About 70 per cent of sugarcane is planted in February-March irrespective of their maturity group. The sugar mills starts their operation by mid-November for which 8-9 months old raw material is brought at mill gate resulting weight loss in comparison to twelve months crop. Cultivation of early maturing sugarcane varieties having higher cane and sugar yield during November is the only solution to save the growers as well as mill owner from economic loss. Sugarcane is an unique heterozygous, often cross pollinated crop which is commercially cultivated by asexual propagation using sett as planting material but improvement in genetic architecture is carried out by sexual means or using fluff (seed). The fluff collected from Biparental mating, selfing or open pollinated arrows are normally used for raising seedling. Clonal selections in seedling, settling and advance generation trials are widely practiced methods for development of commercial varieties in sugarcane. Cane and sugar yields, the two economically important complex characters are polygenic which depend on a number of quantitative as well as juice quality characters. The primary concern of Sugarcane Breeder is to select individual clump during seedling generation on the basis of their phenotypic expression as well as field resistance against diseases and pests. Detailed information's about variability, heritability and genetic advance of economic characters are essential for success in breeding research. Studies on genotypic and phenotypic coefficient of variation show the extent of variability present among the clones for various characters. Estimates of heritability for traits have predictive role expressing the reliability of phenotypic values as a guide to breeding value. The extent of variability and heritability estimates are also important to know the magnitude and type of gene action present in the population which form the basis for designing an effective breeding programme. Red rot, smut and wilts are major diseases which cause losses in terms of cane yield and sucrose content. Of these, Red rot is the most dreaded one and the losses may be as high as 100 per cent. Preventive measures like use of resistant varieties, seed treatment before planting prove to be most effective in controlling the disease and eco-friendly too. Keeping all these points in view estimation of variability in red rot inoculated and uninoculated early maturing sugarcane clones for cane yield and juice quality traits was made to find out the desire traits in the present investigation which can be utilized by sugarcane researchers to get high yield and high sugar in early phage of crushing and also its can be further utilization for sugarcane crop improvement programme.

\section{Materials and Methods}

Materials were 29 early maturing clones viz, CoX 09702, CoX 09121, CoX 09123, CoX 09125, CoX 09169, CoX 09240, CoX 09257, 
CoX 09296, CoX 09328, CoX 09402, CoX 09415, CoX 09428, CoX 09433, CoX 09478, CoX 09489, CoX 09490, CoX 09503, CoX 09531, CoX 09547, CoX 09550, CoX 09552, CoX 09556, CoX 09619, CoX 09642, CoX 09647, CoX 09658, CoX 09715, CoX 09726, and BO 153(Std.) and six different isolates viz, CoSe 95422 from Majholia, BO 138 from Narkatiaganj, CoBln 07501 from Harinagar, CoS 8436 from Riga, BO 145 and CoB 07430 from Pusa of red rot pathogen collected from different parts of sugarcane growing areas of Bihar and provided by the pathological department of Sugarcane Research Institute, RAU, Pusa. All the 29 clones were planted during 2012-13 in RBD with three replications at RAU, Pusa Farm with recommended agronomical package and practices. Observations were recorded in two different conditions from given set of clones one is un-inoculated condition and another is inoculated condition. Twenty observations were recorded in un-inoculated clones whereas eight observations were recorded in inoculated clones.

The observations on germination percentage at 45 days after planting and number of shoots at 120 Days and 240 days after planting were recorded on per plot basis. Leaf area index were taken in the month of September. The number of millable canes in thousands per hectare and cane yield in tonnes per hectare was also recorded on per plot basis at the time of harvesting. Cane height in $\mathrm{cm}$ were taken on five randomly selected plants, cane diameter in $\mathrm{cm}$ were recorded on six plants randomly selected, single cane weight in Kg's was recorded on five canes selected randomly from each plot and replication at the time of harvesting. The juice quality characters (Brix percentage, Pol percentage and Purity percentage) were recorded in the month of mid-November, mid-December and midJanuary. For observation of the juice quality character five healthy millable canes were used. Disease scoring has been done in the month of November.

\section{Method for disease score (0-9 scale)}

To find out the extent of variability for resistance in sugarcane genotypes, within the field trial which was conducted at Pusa farm 20 canes of each genotypes were artificially inoculated by adopting plug method (Mishra and Srivastava, 1996) in the second week of August with a mixture of six isolates of Colletotrichum falcatum. All the isolates were isolated from collected disease samples of CoSe 95422, BO 138, CoBln 07501, BO 145, $\mathrm{CoB}$ 07430, $\mathrm{CoS} 8436$ varieties. Inoculation was done in the middle of third or fourth exposed internode from the bottom.

Holes were made with the help of inoculator and a bit of 7 days old mixed inoculum was injected into the hole and sealed immediately with wax coated papers. After 60 days of inoculation, inoculated canes were split opened longitudinally. Condition of top, lesion width, nodal transgression and nature of the white spots were observed in each clone and graded as per the international scale (0-9 scale) (Srinivasan and Bhat, 1961).

\section{Condition of top}

Green $=0$

Yellow/ dry $=1$

Lesion width above inoculated internodes was assigned the score

If one third of cane width affected $=1$

If two third of cane width affected $=2$

If whole width of cane affected $=3$

Nature of white spot assigned score of

White spot restricted $=1$

White spot progressive $=2$ 
Nodal transgression

If one node crossed $=1$

If two nodes crossed $=2$

If three or more than three nodes crossed $=3$

Average of the total score was taken from assigning the grade and the varieties were graded as per the international scale. The international scale have been below

\section{Statistical analysis}

The analysis of variance was carried out following usual procedure as suggested by Panse and Sukhatme (1967).

In order to assess and quantify the genetic variability among the genotypes for the characters under study, Estimation of variance components viz, phenotypic variances $\left(\sigma^{2} p\right)$ and genotypic variances $\left(\sigma^{2} \mathrm{~g}\right)$ were estimated using the following formula as suggested by Panse and Sukhatme (1967)

$\sigma^{2} \mathrm{~g}=\frac{M S S(\text { genotypes })-\sigma^{2} e}{r}$

$\sigma^{2} p=\sigma^{2} g+\sigma^{2}$ e [When Cov. G x E=0]

Where,

$\sigma^{2} \mathrm{e}=$ Environmental variance i.e. error variance $=$ MSS (error) and $r=$ Number of replication

Genotypic coefficient of variability (GCV)

$\mathrm{GCV}=\sqrt{\frac{\sigma^{2} \mathrm{~g}}{\overline{\mathrm{x}}}} \times 100$

Where,

$\sigma^{2} \mathrm{~g}=$ Genotypic variance and $\overline{\mathrm{X}}=$ Population mean
Phenotypic coefficient of variability (PCV)

$\mathrm{PCV}=\sqrt{\frac{\sigma^{2} \mathrm{p}}{\bar{x}}} \times 100$

Where, $\sigma^{2} \mathrm{p}=$ Phenotypic variance and $\overline{\mathrm{X}}=$ Population mean

GCV and PCV values were categorized as low (0-10\%), moderate (10-20\%) and high (20\% and above)

Heritability (Broad sense) in broad sense was estimated as the ratio of genotypic to the phenotypic variance and was expressed in percentage. It was calculated by the formula given by Johanson et al., (1955a).

$h^{2}($ Broad sense heritability $)=\frac{\sigma^{2} g}{\sigma^{2} p} \times 100$

Where,

$\sigma^{2} \mathrm{~g}=$ Genotypic variance, $\sigma^{2} \mathrm{p}=$ Phenotypic variance and $h^{2}=$ Heritability (broad sense heritability)The heritability was categorized as low, moderate and high as given by Robinson et al., (1949).0-30\%: Low, 30-60\%: Moderate and 60\% and above: High.

Genetic advance was estimated by using the formula suggested by Lush (1949) and followed by Johnson et al., (1955a) and Allard (1960).

Genetic advance $($ G.A $)=K . \sigma p \cdot h^{2}$

Where, $\mathrm{K}=$ Selection differential which is 2.06 at $5 \%$ selection intensity in large sample from normally distributed population, Phenotypic standard deviation and $\mathrm{h}^{2}=$ Heritability in broad sense

Genetic advance as percentage of mean was calculated by following formula: 
$\mathrm{GA}($ as per cent of mean $)=\frac{\mathrm{GA}}{\overline{\mathrm{x}}} \times 100$

Where,

GA $=$ Genetic advance and $\bar{X}=$ Mean of the character

Genetic advance as per cent mean was categorized as low, moderate and high as given by Johnson et al., (1955a).It is as follows.

$0-10 \%$ : Low

10-20\%: Moderate

20\% and above: High

All the statistical analyzed data are being presented in Tables 2, 3, 4 and 5 for estimation of variability in red rot inoculated and un- inoculated early maturing sugarcane clones for cane yield and juice quality traits.

\section{Results and Discussion}

Disease score was done following the standard method in 0-9 scale. The result is being presented in Table 1. Twenty nine clones of early maturity group were tested to find out the levels of their resistance against red rot by employing plug method of inoculation. The inoculated canes were split opened after 60 days and were assessed for their resistance on 0-9 scale. Data on Table 1 revealed that out of twenty nine clones three clones namely CoX 09715, CoX 09726 and CoX 09428 have shown resistant reaction against red rot disease with mean scores of $1.2,1.4$ and 1.5 , respectively.

Twelve clones including check have been rated moderately resistant with mean score ranging between 2.2 to 3.8 , these were $\mathrm{CoX}$ 09550 (2.2), CoX 09296 (2.4), BO 153 (Check, 2.5), CoX 09503 (2.7), CoX 09072 (2.8), CoX 09556 (3.0), CoX 09123 (3.2), CoX 09121 (3.4), CoX 09547 (3.5), CoX
09647 (3.5), CoX 09257 (3.6) and CoX 09478 (3.8). Whereas eight clones were found moderately susceptible viz. CoX 09490 (4.2), CoX 09402 (4.4), CoX 09169 (4.6), CoX 09489 (4.8), CoX 09531 (5.0), CoX 09328 (5.4), CoX 09612 (5.6) and CoX 09619 (5.8). Altogether four clones viz. CoX 09552 (6.2), CoX 09658 (6.5), CoX 09415 (7.1) and CoX 09433 (7.6) were rated as susceptible and two clones were graded as highly susceptible with mean scores 8.2 (CoX 09240) and 8.6 (CoX 09125). Thus on the basis of disease reaction genotypes of experiment showed variation from resistant to high susceptible as earlier workers namely Kalaimani and Natarajan (1994 and 1997), Kalaimani et al., (2001), Shukla et al., (2002), Misra and Singh (2003) Bakshi et al., (2006), Mishra et al., (2004), Kumar and Kumar (2005) and Pandya et al., (2007) also found similar results after inoculation of red rot pathogens.

The analysis of variance Tables 2 and 3 indicated significant differences among the clones for all characters. Wider range was observed for number of shoots at 240 days, plant height, number of millable canes, fibre per cent at harvest, cane and sugar yield in un-inoculated canes, whereas in inoculated canes, disease score, sugar and cane yield, single cane weight and fiber per cent showed wide range of variation.

The range of variation was much wider for number of shoots at 240 days, number of shoots at 120 days, germination percentage at 45 days, fiber per cent, plant height, cane yield and sugar yield when un-inoculated canes were evaluated as indicated in Table 4. In case of juice quality characters like Brix, Pol and Purity per cent during these entire months single cane weight and cane diameter the range of variations were comparatively narrow. In inoculated canes the range of variation was widest in case of disease score, sugar yield, cane yield, single cane weight and fiber per cent as indicated in Table 5, 
these ranges were much wider than uninoculated canes. The juice quality characters had narrow range of variation within inoculated cane but it was wider when compared with the ranges of un-inoculated canes. It is due to the fact that the clones has wide range of variation from resistance to highly susceptible reaction against red rot disease resulting into variation in morphological and juice quality characters.

Table.1 Disease reaction of 29 sugarcane clones against red rot disease (0-9 Scale)

\begin{tabular}{|c|c|c|c|}
\hline Sl. No. & Clones & Mean Scoring & Disease Reaction \\
\hline 1 & CoX 09647 & 3.5 & MR \\
\hline 2 & CoX 09726 & 1.4 & $\mathrm{R}$ \\
\hline 3 & CoX 09531 & 5.0 & MS \\
\hline 4 & CoX 09415 & 7.1 & S \\
\hline 5 & CoX 09547 & 3.5 & MR \\
\hline 6 & CoX 09619 & 5.8 & MS \\
\hline 7 & CoX 09402 & 4.4 & MS \\
\hline 8 & CoX 09556 & 3.0 & MR \\
\hline 9 & CoX 09503 & 2.7 & MR \\
\hline 10 & CoX 09552 & 6.2 & $S$ \\
\hline 11 & CoX 09125 & 8.6 & HS \\
\hline 12 & CoX 09240 & 8.2 & HS \\
\hline 13 & CoX 09433 & 7.6 & $\mathrm{~S}$ \\
\hline 14 & CoX 09072 & 2.8 & MR \\
\hline 15 & CoX 09658 & 6.5 & $\mathrm{~S}$ \\
\hline 16 & CoX 09490 & 4.2 & MS \\
\hline 17 & CoX 09489 & 4.8 & MS \\
\hline 18 & Cox 09328 & 5.4 & MS \\
\hline 19 & CoX 09296 & 2.4 & MR \\
\hline 20 & CoX 09478 & 3.8 & MR \\
\hline 21 & CoX 09169 & 4.6 & MS \\
\hline 22 & CoX 09123 & 3.2 & MR \\
\hline 23 & CoX 09428 & 1.5 & $\mathrm{R}$ \\
\hline 24 & CoX 09257 & 3.6 & MR \\
\hline 25 & CoX 09642 & 5.6 & MS \\
\hline 26 & CoX 09715 & 1.2 & $\mathrm{R}$ \\
\hline 27 & CoX 09550 & 2.2 & MR \\
\hline 28 & CoX 09121 & 3.4 & MR \\
\hline 29 & BO $153(\mathrm{C})$ & 2.5 & MR \\
\hline
\end{tabular}


Table.2 Mean sum of squares for different traits of un-inoculated sugarcane clones

\begin{tabular}{|c|c|c|c|c|}
\hline Sl. No. & Characters & $\begin{array}{l}\text { Treatment } \\
(\mathrm{df}=28)\end{array}$ & $\begin{array}{l}\text { Replication } \\
(\mathrm{df}=2)\end{array}$ & $\begin{array}{c}\text { Error (df } \\
=56)\end{array}$ \\
\hline 1 & Germination percentage at $45 \mathrm{DAP}$ & $123.97 * *$ & 27.3 & 14.54 \\
\hline 2 & Number of Shoots at 120 DAP (000/ha) & $1030.89 * *$ & 14.32 & 58.62 \\
\hline 3 & Number of Shoots at 240 DAP $(000 / \mathrm{ha})$ & $1244.08 * *$ & 35.02 & 50.81 \\
\hline 4 & Leaf Area Index & $0.17 * *$ & 0.0002 & 0.0014 \\
\hline 5 & Cane Diameter $(\mathrm{cm})$ & $0.13 * *$ & 0.0037 & 0.014 \\
\hline 6 & Plant Height $(\mathrm{cm})$ & $3439.91 * *$ & 95.69 & 118.97 \\
\hline 7 & Number of Millable Canes (000/ha) & $315.36 * *$ & 5.14 & 20.34 \\
\hline 8 & Single Cane Weight $(\mathrm{Kg})$ & $0.0166^{* *}$ & 0.0001 & 0.0009 \\
\hline 9 & Brix in November & $3.37 * *$ & 0.15 & 0.12 \\
\hline 10 & Brix in December & $3.02 * *$ & 0.085 & 0.21 \\
\hline 11 & Brix in January & $2.999 * *$ & 0.18 & 0.159 \\
\hline 12 & Pol percentage in November & $2.6048 * *$ & 0.218 & 0.125 \\
\hline 13 & Pol percentage in December & $1.8556 * *$ & 0.07 & 0.1636 \\
\hline 14 & Pol percentage in January & $0.60 * *$ & 0.085 & 0.1022 \\
\hline 15 & Purity percentage in November & $3.30 * *$ & 1.16 & 0.597 \\
\hline 16 & Purity percentage in December & $6.0992 * *$ & 0.1746 & 1.0036 \\
\hline 17 & Purity percentage in January & $14.8828 * *$ & 3.457 & 0.8999 \\
\hline 18 & Fibre percentage & $13.9014 * *$ & 0.372 & 0.387 \\
\hline 19 & Sugar Yield (t/ha) & $13.948 * *$ & 0.2355 & 0.1944 \\
\hline 20 & Cane yield (t/ha) & $219.96 * *$ & 0.88 & 23.93 \\
\hline
\end{tabular}

** Significant at $1 \%$ level

Table.3 Mean sum of squares for different traits of red rot inoculated clones

\begin{tabular}{|c|l|c|c|c|}
\hline Sl. No. & \multicolumn{1}{|c|}{ Character } & $\begin{array}{c}\text { Treatment } \\
(\mathrm{df}=28)\end{array}$ & $\begin{array}{c}\text { Replication } \\
(\mathrm{df}=2)\end{array}$ & $\begin{array}{c}\text { Error (df } \\
=56)\end{array}$ \\
\hline 1 & Disease score (0-9 Scale) & $12.27 * *$ & 0.0262 & 0.0783 \\
\hline 2 & Single Cane Weight (Kg) & $0.05^{* *}$ & 0.0010 & 0.0007 \\
\hline 3 & Brix in January & $8.4005^{* *}$ & 0.0949 & 0.1444 \\
\hline 4 & Pol percentage in January & $9.28^{* *}$ & 0.1416 & 0.1023 \\
\hline 5 & Purity percentage in January & $61.76^{* *}$ & 1.5725 & 5.1256 \\
\hline 6 & Fibre percentage & $12.0483^{* *}$ & 0.0711 & 0.1052 \\
\hline 7 & Sugar Yield (tones/ ha) & $3.6064^{* *}$ & 0.1173 & 0.3745 \\
\hline 8 & Cane yield (tones/ ha) & $635.425^{* *}$ & 11.9252 & 11.2391 \\
\hline
\end{tabular}


Table.4 Genetic parameters of un-inoculated canes for 20 traits of 29 sugarcane clones

\begin{tabular}{|c|l|c|c|c|c|c|c|c|} 
S.N. & \multicolumn{1}{|c}{ Characters } & Range & Mean & GCV & PCV & $\mathrm{h}^{2}(\%)$ & GA & GAM \\
\hline 1 & Germination \% 45 DAP & $23.92-49.63$ & 36.13 & 16.72 & 19.77 & 71.50 & 10.52 & 29.12 \\
\hline 2 & No. of Shoots at 120 DAP (000/ha) & $63.04-131.11$ & 88.49 & 20.34 & 22.11 & 84.68 & 34.13 & 38.57 \\
\hline 3 & No. of Shoots at 240 DAP (000/ha) & $69.20-145.88$ & 101.11 & 19.73 & 20.95 & 88.67 & 38.69 & 38.26 \\
\hline 4 & Leaf Area Index & $3.42-4.43$ & 3.88 & 6.19 & 6.27 & 97.55 & 0.49 & 12.60 \\
\hline 5 & Cane Diameter (cm) & $1.84-2.73$ & 2.09 & 9.35 & 10.94 & 73.70 & 0.34 & 16.47 \\
\hline 6 & Plant Height (cm) & $195.80-322.27$ & 254.15 & 13.09 & 13.78 & 90.30 & 65.13 & 25.63 \\
\hline 7 & Number of Millable Canes (000/ha) & $82.41-118.23$ & 97.23 & 10.20 & 11.20 & 82.86 & 18.60 & 19.13 \\
\hline 8 & Single cane weight (Kg) & $0.63-0.90$ & 0.78 & 9.32 & 10.10 & 85.09 & 0.14 & 17.70 \\
\hline 9 & Brix \% (Mid Nov) & $17.13-21.23$ & 19.10 & 5.44 & 5.74 & 89.98 & 2.03 & 10.64 \\
\hline 10 & Brix \% (Mid Dec) & $17.87-21.60$ & 19.99 & 4.85 & 5.35 & 82.07 & 1.81 & 9.04 \\
\hline 11 & Brix \% (Mid Jan) & $19.00-22.40$ & 20.79 & 4.68 & 5.06 & 85.60 & 1.85 & 8.92 \\
\hline 12 & Pol \% (Mid Nov) & $14.70-18.02$ & 16.68 & 5.45 & 5.85 & 86.83 & 1.75 & 10.46 \\
\hline 13 & Pol \% (Mid Dec) & $15.44-18.42$ & 17.39 & 4.32 & 4.91 & 77.52 & 1.36 & 7.83 \\
\hline 14 & Pol \% (Mid Jan) & $16.70-18.42$ & 17.82 & 2.29 & 2.91 & 61.89 & 0.66 & 3.71 \\
\hline 15 & Purity \% (Mid Nov) & $84.73-89.10$ & 87.36 & 1.09 & 1.40 & 60.15 & 1.52 & 1.74 \\
\hline 16 & Purity \% (Mid Dec) & $83.63-89.17$ & 87.10 & 1.50 & 1.89 & 62.86 & 2.13 & 2.44 \\
\hline 17 & Purity \% (Mid Jan) & $82.23-89.27$ & 85.79 & 2.52 & 2.75 & 83.82 & 4.07 & 4.75 \\
\hline 18 & Fibre \% & $8.84-17.53$ & 13.91 & 14.35 & 14.53 & 97.43 & 4.06 & 29.17 \\
\hline 19 & Sugar Yield (t/ha) & $7.03-11.37$ & 9.17 & 11.32 & 13.15 & 74.20 & 1.84 & 20.10 \\
\hline 20 & Cane Yield (t/ha) & $57.87-93.25$ & 75.49 & 10.71 & 12.52 & 73.19 & 14.25 & 18.87 \\
\hline
\end{tabular}

Table.5 Genetic parameters of inoculated canes of 29 sugarcane clones

\begin{tabular}{|c|l|c|c|c|c|c|c|c|}
\hline Sl. No. & \multicolumn{1}{|c|}{ Characters } & Range & Mean & GCV & PCV & $\mathbf{h}^{\mathbf{2}}(\boldsymbol{\%})$ & GA & GAM \\
\hline $\mathbf{1}$ & Disease Score (0-9 Scale) & $1.20-8.60$ & 4.30 & 46.89 & 47.34 & 98.11 & 4.11 & 95.67 \\
\hline $\mathbf{2}$ & Single Cane weight (Kg) & $0.36-.83$ & 0.69 & 18.27 & 18.67 & 95.77 & 0.25 & 36.84 \\
\hline $\mathbf{3}$ & Brix \% (Mid Jan) & $14.70-21.90$ & 18.67 & 8.89 & 9.12 & 95.02 & 3.33 & 17.85 \\
\hline $\mathbf{4}$ & Pol \% (Mid Jan) & $10.73-17.92$ & 15.29 & 11.44 & 11.63 & 96.77 & 3.55 & 23.18 \\
\hline $\mathbf{5}$ & Purity \% (Mid Jan) & $67.60-81.17$ & 81.81 & 5.31 & 5.99 & 78.63 & 7.94 & 9.70 \\
\hline $\mathbf{6}$ & Fibre \% & $10.44-18.66$ & 15.18 & 14.16 & 14.22 & 99.17 & 4.41 & 29.06 \\
\hline $\mathbf{7}$ & Sugar Yield (t/ha) & $1.98-10.62$ & 7.03 & 30.44 & 31.08 & 95.93 & 4.32 & 61.41 \\
\hline $\mathbf{8}$ & Cane yield (t/ha) & $31.34-91.47$ & 67.09 & 21.50 & 22.07 & 94.83 & 28.94 & 43.14 \\
\hline
\end{tabular}

International Scale $(0$ - 9) for red rot Disease Scoring

\begin{tabular}{|c|l|}
\hline Score & \multicolumn{1}{|c|}{ Reaction } \\
\hline $0.0-2.0$ & Resistant (R) \\
\hline $2.1-4.0$ & Moderately Resistant (MR) \\
\hline $4.1-6.0$ & Moderately susceptible (MS) \\
\hline $6.1-8.0$ & Susceptible (S) \\
\hline Above 8.0 & Highly susceptible (HS) \\
\hline & \\
\hline
\end{tabular}


The genotypic and phenotypic coefficients of variation were computed for all the twenty and eight characters of un-inoculated and inoculated canes respectively. The numerical values of phenotypic coefficient of variation were higher than their genotypic counterpart indicating the role of environment in manifestation of the characters. Among morphological characters of un-inoculated canes higher phenotypic and genotypic coefficient of variation were recorded for number of shoots at 120 days, number of shoot at 240 days, germination percentage at 45 days, fiber percentage and plant height. The magnitude of phenotypic and genotypic coefficient of variations were moderately higher order for number of millable cane, single cane weight, sugar and cane yield at harvest. The PCV and GCV of qualitative characters like Brix, Pol and Purity per cent during all the three months were comparatively of lower magnitude, the values of Purity per cent being lowest. In inculcated canes, higher GCV and PCV were recorded for disease score followed by sugar and cane yield. They were moderately higher for single cane weight, fiber per cent and Pol per cent in January. The magnitude was lower for Brix in January and for Purity per cent being lowest. Kamat and Singh (2001) found similar result i.e. higher genotypic and phenotypic coefficient of variation for germination percentage, number of shoots, leaf area index, cane height, number of millable canes, single cane weight and cane yield. Sanjeev et al., (2001) also observed higher coefficient of variation at genotypic and phenotypic level for cane yield and number of millable canes and tillers. Ravishankar et al., (2004) observed high genotypic and phenotypic variances for cane yield and moderately high for number of tillers and number of millable canes. Sabitha et al., (2007) reported moderate to high estimates of phenotypic (PCV) and genotypic (GCV) coefficient of variations for shoot population at 120 days, shoot population at 240 days, plant height, number of millable canes, cane yield and sugar yield, while low for single cane weight, juice sucrose per cent and cane diameter. Singh et al., (2010) found sufficient variability and phenotypic and genotypic coefficient of variation for number of shoots at 120 and 240 days, cane yield, sugar yield, number of millable canes, germination parentage at 45 days, single cane weight and cane height. Tyagi et al., (2011) revealed that coefficients of variation were high for number of millable canes, cane yield, cane weight and for sugar yield. However, according to Burton (1952) it is not possible to determine the amount of heritable variation with the help of genetic coefficient of variation alone. He suggested the study of genetic coefficient of variation along with heritability estimates to obtain the best picture of the extent of heritable variation. Higher heritability estimates were recorded in uninoculated canes for the characters leaf area index, fiber percentage, plant height, Brix in November, December and January, number of shoots at 120 and 240 days, Pol percentage in November, single cane weight, Purity percentage in January, number of millable canes. Moderate estimates of heritability were observed for sugar yield, cane yield, cane diameter at harvest and germination percentage at 45 days. Higher estimates of heritability in inoculated canes were recorded for all the characters studied viz. fiber percentage, disease score, Brix, Pol and Purity percentage in January, sugar yield, single cane weight and cane yield. According to Johnson et al., (1955a) heritability estimates along with genetic gain are more efficient than heritability estimates alone in predicting the final outcome of selection. Swarup and Changle (1962) have also suggested the study of heritability along with genetic gain to obtain the best estimates of heritable variation. The higher genetic advances in uninoculated canes were recorded for the 
characters plant height, number of shoots at 120 and 240 days. The estimates were moderately high for number of millable canes, cane yield and germination percentage at 45 days. Higher genetic advance in inoculated canes was recorded for cane yield only. Genetic advance as per cent of mean were of higher magnitude in uninoculated canes for number of shoots at 120 and 240 days, fiber percentage, germination percentage at 45 days, plant height and sugar yield. The characters number of millable canes, cane yield, single cane weight, cane diameter, leaf area index, Brix in November and Pol percentage in November showed moderate genetic advance as per cent of mean. In inoculated canes higher estimate of genetic advance as per cent of mean was recorded for disease score, sugar yield, cane yield, single cane weight, fiber percentage and Pol percentage in January. The character, Brix in January showed moderate and Purity percentage in January showed lower estimates of genetic advance as per cent of mean. Disease score (0-9 scale) recorded highest values for genetic coefficient of variation and genetic advance as per cent of mean but the estimates of heritability was next to highest for fiber per cent in inoculated cane. The characters cane and sugar yield had also higher estimates for the three parameters. The other characters viz. single cane weight, fiber per cent and Pol per cent in January also showed moderately higher values for these genetic parameters. It would be advisable to screen the clones for their disease score, cane and sugar yield, single cane weight, fiber per cent and Pol per cent in January while selecting high yielding, quality clones in advance clonal generations. Tyagi and Singh (2000) reported higher genetic advance and heritability for stalk weight. Kamat and Singh (2001) reported that germination percentage, number of shoots, leaf area index, cane height, number of millable canes, single cane weight and cane yield had moderates to high heritability and genetic advance. Sanjeev et al., (2001), Thippeswamy et al., (2001), Ravishankar et al., (2003), Agrawal (2003), Ravishankar et al., (2004), Krishna et al.,(2004) and Hapase and Repale (2004) found similar results for the traits, number of millable canes, number of tillers at 240 , cane yield, cane height, cane girth, single cane weight, leaf area, germination percentage, Brix and sucrose percentage showed high heritability and genetic advance expressed as a percentage of the population mean. Patel et al., (2006) reported that high heritability coupled with high genetic advance observed for single cane weight. Sabitha et al., (2007) reported that plant high, shoot population at 120 and 240 days, single cane weight, number of millable canes, cane yield were recorded moderate to high estimates of heritability and genetic advance as per cent of mean. Rahman et al., (2009) also observed that number of tillers, number of millable canes, stalk height and cane yield showed high heritability and genetic advance in mean percentage. Mali et al., (2010) observed that number of millable tillers and single cane weight showed high genetic advance coupled with higher heritability. Singh et al., (2010) studied that number of shoots at 120 and 240 days and number of millable canes possessed high heritability coupled with higher genetic advance. Tyagi et al., (2011) also observed high heritability values for Juice Brix, Juice sucrose $\%$, cane weight, cane yield and sugar yield while the lowest heritability values were observed for cane diameter. The genetic advance was high for cane weight, cane height, number of millable canes and cane yield. The number of shoots at 120 and 240 days, fiber per cent and plant height recorded higher values for genetic coefficient of variation, heritability and genetic advance as percentage of mean.

The other five characters viz. single cane weight, number of millable cane, sugar yield, 
cane yield and germination percentage at 45 days had also shown moderate to high values for these parameters. Among the juice quality characters, Brix during November, December and January and Pol per cent in January showed heritability estimates of higher order but their values for genetic coefficient of variation and genetic advance as per cent mean were quiet low except Brix and Pol per cent during November for which genetic advance as per cent of mean were moderate. Therefore, is appears that selection for number of shoots at 120 and 240 days, fiber per cent, plant height, single cane weight, number of millable canes, sugar and cane yield and germination per cent at 45 days should be effective and rewarding.

\section{References}

Agrawal, K. B., 2003. Estimates of variation and heritability of some quantitative characters in sugarcane. Annals of Agricultural Research. 24(2): 379-382.

Bakshi, Ram Singh, Narendra and Sahi, B. K. 2006. Selection for juice quality and red rot disease index in sugarcane (Saccharum officinarum L.). Indian Journal of Genetics and Plant Breeding, 66(2): 151-152.

Burton, G. W., 1952. Quantitative inheritance in grasses. Proc. $6^{\text {th }}$ Int. Grassland Congr. 1: 277-283.

Doule, R. B., and Balasundaram, N. 2002. Genetic variability in sugar yield and its components for selection of sugarcane. Journal of Maharashtra Agricultural Universities. 27(3): 326-327.

Fisher, R. A., and Yates, F. 1938. Statistical tables for Biological, Agricultural and Medical Research. 5 August. Oliver and Boyd. Edinburgh.

Gagan Deep, Mehla, A. S., Punia, M. S. and Kadian, S. P. 2004. Studies on variability, heritability and genetic gain for yield, its components and quality traits in sugarcane (Saccharum complex). Indian-Sugar. 54(9): 733737.

Ghosh, J., \& Singh, J. R. P. 1996. Variability in early maturing clones of sugarcane. Co- operative Sugar. 27 (5): 341-344.

Hapase, R. S., and Repale, J. M. 2004. Variability studies of some quantitative and qualitative characters in sugarcane varieties. Indian Sugar. 54(3): 205-210.

Johnson, H. W., Robinson, H. F. and Comstock, R. E. 1955a. Estimates of genetic and environmental variability in soybeans. Agron. J. 47: $314-318$.

Kadian, S. P., Chander, Kishor and Sabharwal, P. S. 1997. Genetic variability and heritability in sugarcane. Indian Sugar.46 (12): 973-975.

Kadian, S. P., Singh, J. V., Sabharwal, P. S. and Yadav, J. S. 1997. Variability, heritability and genetic advance for yield and yield contributing characters in sugarcane (Saccharum hybrid spp.). Agricultural Science Digest Karnal. 17(1): 51-53.

Kalaimani, T., and Natarajan, S. 1994. Screening of sugarcane clones / varieties against red rot (Colletotrichum falcatum, Went.). Ind. Suagr, 44: 7, 497-498.

Kalaimani, T., and Natarajan, S. 1997. Sugarcane genotypes resistant to red rot caused by Colletotrichum falcatum. Plant disease research, 12: 2, 138-140.

Kalaimani, T., Natarajan, S., Rajkumar, M. and Panneer Selvam, R. 1997. Screening of sugarcane clones/ varieties for resistance to red rot (Colletotrichum falcatum, Went.). Co-operative Sugar, 28; 9, 689.

Kalaimani, T., Rajakumar, M., Venkatachalam, S. R., Shah, S. E., Purushothoman, R. S., Babu, C. and Giridharan, S. 2001. Varietal resistance of sugarcane red rot caused by Colletotrichum falcatum Went. Indian 
Sugar. 50(11): 793-795.

Kamat, D. N., and Singh, J. R. P. 2001. Variability in sugarcane undr rainfed condition. Sugar Tech. 3 (1): (1\&2): 6567.

Kumar, B., and Kumar, S. 2005. Changes in cane biometrix and juice quality due to red rot infection. Indian Sugar. 55(9): 67-69.

Kumar, R., and Singh, J. R. P. 1999. Variability in sugarcane under waterlogged condition. Journal of Applied Biology. 9(2): 140-142.

Kumar, S., Kumar, B. \& Kumar, V. 2000. Deterioration on juice quality of sugarcane due to pathotypes of red rot pathogen. Ann. Agri. Bio. Res., 5 (1): 31-35.

Mali, S. C., Patel, A. I., Patel, D. U. and Patel, C. L. 2010. Variability, correlation, path analysis and genetic divergence in sugarcane (Saccharum spp.). Research on Crops, 11(2): 497-504.

Mishra, M. K., Mishra, P. K., Panda, S. K. and Mishra, P. J. 2004 Sugarcane varietal reactions to red rot caused by Colletotrichum falcatum by different inoculation methods. Indian Sugar. 54(4): 285-288.

Mishra, S. R., and Srivastava, T. N. 1996. Evaluation of pre zonal/ zonal varieties / genotypes for resistance to red rot and smut. In the technical report of the AICRP on sugarcane. Plant Pathology, IISR, Lucknow, PP. 5 - 10.

Misra, S. C., and Singh, A. K. 2003. Evaluation of sugarcane genotypes for resistance against red rot caused by Colletotrichum falcatum. Indian Sugar. 52(11): 923-924.

Niraj Kumar, and Singh, J. R. P. 2004. Screening of sugarcane varieties against red rot disease. Indian Sugar. 53(10): 803-805.

Pandya, J. R., Makwana, K. V. and Patel, M. B. 2007. Evaluation of sugarcane genotypes for resistance against Colletotrichum falcatum Went. Indian Sugar. 57(1): 25-27.

Panse, V. G., and Sukhatme, P. V. 1967. Statistical methods of agricultural workers $2^{\text {nd }}$ edn. pp. 381, ICAR, publication, New Delhi.

Rahman, M. M., and Bhuiyan, M. S. R. 2009. Variability, heritability and genetic advanced for cane yield and its components in some indigenous and exotic promising clones of sugarcane (Saccharum officinarum L). Indian Sugar. 59(2): 35-42.

Ravishankar, C. R., Ramappa, H. K., Prakash, P. and Puttarama Naik 2003. Genetic variability and correlation studies in sugarcane. Environment and Ecology. 21(4): 951-954.

Ravishankar, C. R., Ramappa, H. K., Prakash, P., Gowda, S. N. S. and Shivakumar, N. 2004. Genetic variability and correlations in sugarcane (Saccharum spp.) germplasm for quantitative characters. Environment and Ecology, 22(Spl-3): 569-571.

Sabitha, N., Rao, K. P., Rao, C. P. and Rao, M. S. 2007. Genetic variation, heritability and genetic advance for yield components in sugarcane. Sugar Tech. 9(4): 290-292.

Sanjeev Kumar, Singh P. K. and Singh, j. 2001. Genetic variability, heritability, genetic advance and correlation in sugarcane under moisture deficit condition. Indian Journal of Sugarcane Technology. 16 (1): 32-35.

Sarma, P. C., and Bora, G. C. 2005. Screening of sugarcane genotypes for resistance to rot (Colletotrichum falcatum Went.). Indian Sugar. 55(5): 29-31.

Shukla, R. K., Verma, K. P. and Singh, R. R. 2002. Screening of sugarcane genotypes against red rot (Colletotrichum falcatum) Went. Indian Sugar. 52(1): 25-26. 
Singh, A. P., Chatterjee, A. and Nema, G. K. 1996. Genetic variability in sugarcane (Saccharum sp. complex). Crop Research Hisar. 12(2): 162-164

Singh, M. K., Pandey, S. S., Rakesh, Kumar and Singh, A. K. 2010. Estimation of genetic variability, heritability and genetic advance in mid-late maturing clones of sugarcane. Environment and Ecology. 28(4): 2301-2305.

Spencer, G. L., and Meade, G. P. 1955. Cane Sugar Hand Book, John Willey and Sons, London.

Spencer, G. L., and Meade, G. P. 1969. A handbook for cane sugar manufacture and its chemistry. Elsevier and Co. London.

Srinivasan, K. V., and Bhat, N. R. 1961. Red rot of sugarcane criteria for grading resistance. J. Indian Bot. Society, 40:
$566-577$

Swaroop, V. R., and Changle, D. S. 1962. Studies on genetic variability in sorghum1. Phenotypic variation and its heritable components in some important quantitative characters contributing towards yield. Indian J. Genet. 22: 3136.

Thippeswamy, S., Kajjidoni, S. T., Salimath, P. M., Goud, J. V. and Chetti, M. B. 2001. Variability, heritability and genetic advance for cane yield and its components in sugarcane. Karnataka $J$. of Agri. Sci. 14(1): 30-34.

Tyagi, V.K., Sharma, Satish and Bhardwaj, S. B. 2011. A study on the nature and magnitude of variations in different traits in sugarcane. Electronic Journal of Plant Breeding. 2(3): 334-341.

\section{How to cite this article:}

Sara Neelofer and Balwant Kumar. 2017. Estimation of Variability in Red Rot Inoculated and Un- Inoculated Early Maturing Sugarcane Clones for Cane Yield and Juice Quality Traits. Int.J.Curr.Microbiol.App.Sci. 6(10): 2347-2359. doi: https://doi.org/10.20546/ijcmas.2017.610.277 